\title{
Microsporogenesis in Hydrobryum griffithii (Wallich ex Griffith) Tulsane (Podostemaceae) from North East India
}

\author{
H. Lalruatsanga \\ Department of Botany, Pachhunga University College-796001
}

\begin{abstract}
Flowers of Hydrobryum griffithii are cleistogamous, enclosed by a thin membranous spathe. The two anthers are borne on a forked filament placed adjoining to the stigmatic lobes. The two anther primordia initiated far before the development of gynoecium and enclosed by a distinct membranous perianth lobe. The anther primordium comprises a mass of undifferentiated meristematic cells covered with a unilayered dermatogen, thus conforming to tunica-corpus concept. A row of 3-4 cells in the hypodermis differentiated into an archesporium in each anther lobe
\end{abstract}

Keywords: Podostemaceae, Hydrobryum griffithii, Mawsynram, North east India, pollen viability.

\section{Introduction}

Podostemaceae is the largest family of strictly aquatic angiosperm with 49 genera and 270 species worldwide [1]; Podostemaceae display many unique mor- phological, anatomical and ecological features, and stands clearly apart from all other angio- spermous families. Most of the previous workers mainly confined their studies on female gametophyte. Though Khosla et al [2] and Mukkada [3] studied the reproductive biology in some members of Podostemaceae, the ontogeny and development of anthers and microsporogenesis were studied only to a limited extent. Therefore, the present research describes the development of anther from the ontogeny till the pollen formation in Hydrobryum griffithii (Wallich ex Griffith) Tulsane.

\section{Materials and Methods}

Flowers of Hydrobryum griffithii (Wallich ex Griffith) Tulsane at various developmental stages were collected from a stream at Specimen collection is carried out in stream at fossil park, Janiaw, Lawbah region; about $6 \mathrm{~km}$ away from Mawsynram, located in East Khasi Hills District, Meghalaya State, India $\left(92.10^{\circ} \mathrm{N}-25.25^{\circ} \mathrm{E}\right)$ at an altitude of $1300 \mathrm{~m}$. For the light microscopy a rotary micro- tome was employed to make 7-10 $\mu \mathrm{m}$ thick sec- tions that were stained variously. Photomicrographs were taken using Nikon E600 and Leitz fluorescence microscopes. External morphology of the stamen and pollen grains were observed by using Joel (JSM6360) scanning electron microscope.

\section{Results}

Anthor Development and microsporogenesis:

The two anther primordia initiated far before the development of gynoecium and enclosed by a distinct membranous perianth lobe(a)

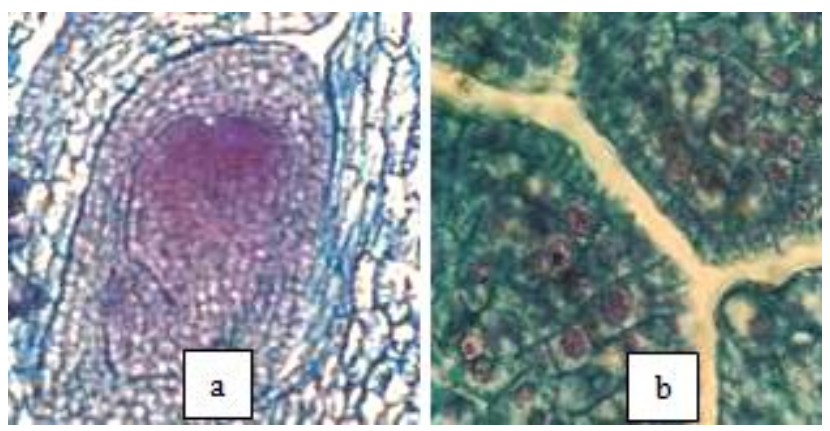

The anther primordium comprises a mass of undifferentiated meristematic cells covered with a unilayered dermatogen (b), thus conforming to tunica-corpus concept. The two anther primordia grow in height by intercalary meristematic activity of andropodium to form biforked filament (c).
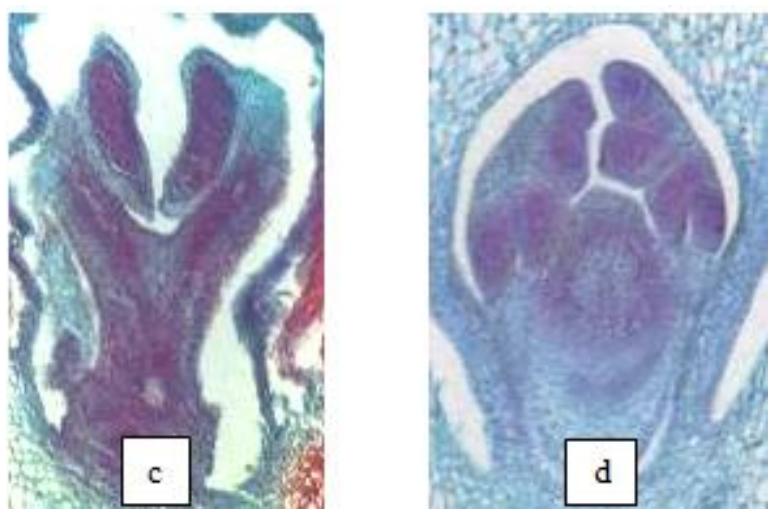

After attaining a height of $10-13 \mu \mathrm{m}$, the four anther primordial loci are differentiated on the adaxial side, so that all the four lobes of each anther are facing towards the stigma (d). The flowers of Hydrobryum griffithii are bisexual which have two tetrasporangiate anthers.

A row of 3-4 cells in the hypodermis differentiated into an archesporium in each anther lobe. Each archesporial cell is very conspicuous with dense cytoplasm and a large prominent nucleus. The already differentiated archesporial cells divides anticlinally to produce more archesporial initials. Each archesporial initial divides periclinally 


\section{International Journal of Science and Research (IJSR) \\ ISSN (Online): 2319-7064 \\ Index Copernicus Value (2013): 6.14 | Impact Factor (2014): 5.611}

producing two cells of unequal size. The much larger inner row of cells became primary sporogenous cells and the smaller outer cells form primary parietal cells (Plate $4.2 \mathrm{e}$ ).

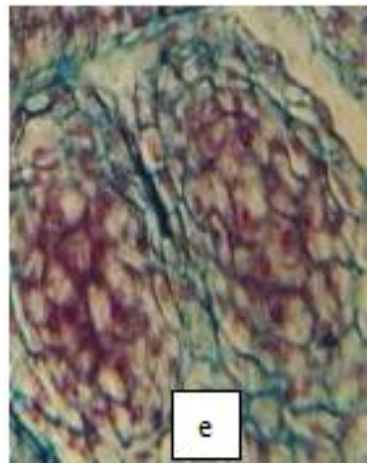

The primary parietal cells undergo only one periclinal division to form two-layered secondary parietal layer. The outer one functions as endothecium, while the inner one directly transformed into tapetum (e). Middle layers are absent. The endothecial layers acquire thickenings only when the pollen grains are formed. More or less all the cells of anther lobe bear thickenings except the vasculature. The cells of endothecium and tapetum are fully laddened with starch grains. Callose deposition in the meiocytes separates the individual microspore mother cells, enclosed within the callose wall layer (f \& g).

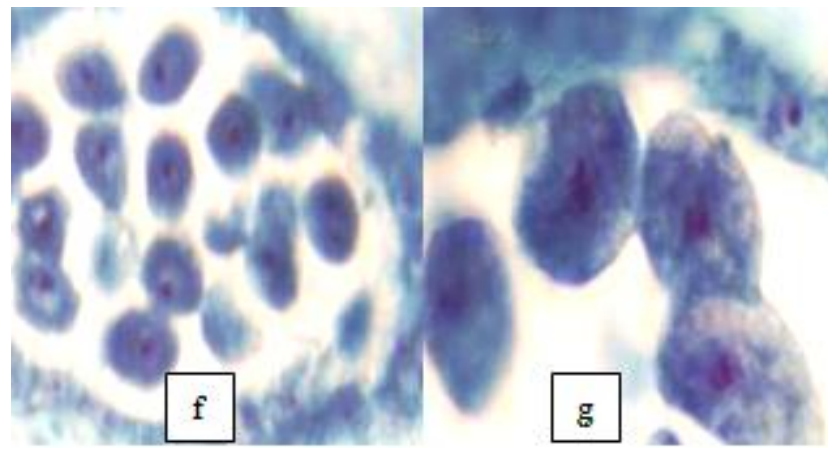

Meiosis and Cytokinesis:

The pollen grains are arranged in isobilateral and decussate arrangement. Meiosis is uniform in all the microspore mother cells within the thecum, but not in adjacent anther locule (h). The callose wall gets dissolved with the completion of cytokinesis, but before the start of pollen wall deposition. During the onset of meiosis in the microspore mother cells, nuclear spindle appears on either side of metaphase nucleus; as a result, a binucleate microspore formed (i).
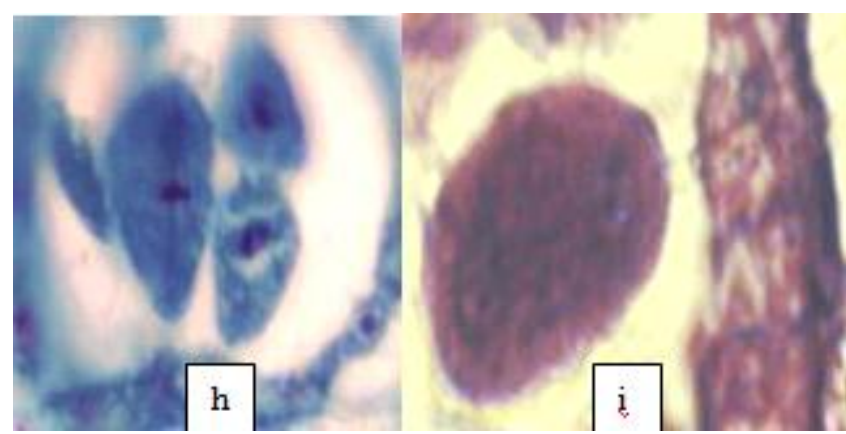

Simultaneously, centrifugal cell plate formation is initiated in a transverse plane that a dyad is resulted (j). While microspore mother cells are undergoing meiosis, the adjacent tapetal cells show granular appearances, which indicate the synthesis of orbicules or pro-ubisch bodies (k).

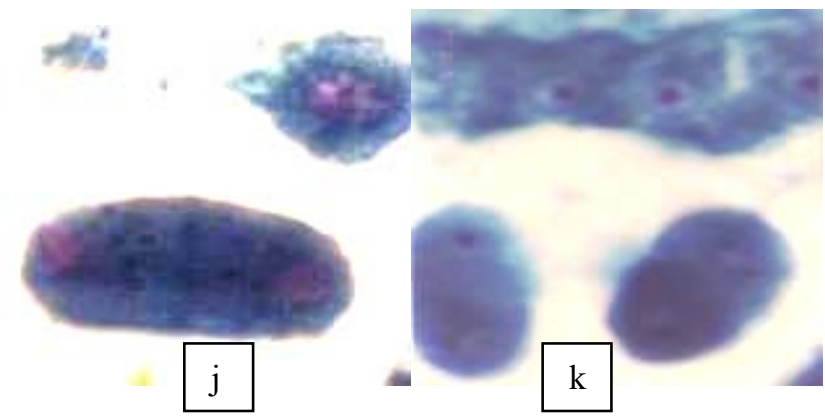

The nuclei of dyad undergo Meiosis-II; with which, the tapetum becomes binucleate $(\mathrm{k})$. The extent and progress of cell division was not uniform in the two sister nuclei. The microspore dyad then becomes four nucleate and simultaneously a cell plate is formed in between the newly formed microsporocytes. So that a tetrad is formed arranged either in opposite decussate (1) or isobilateral configuration (m).

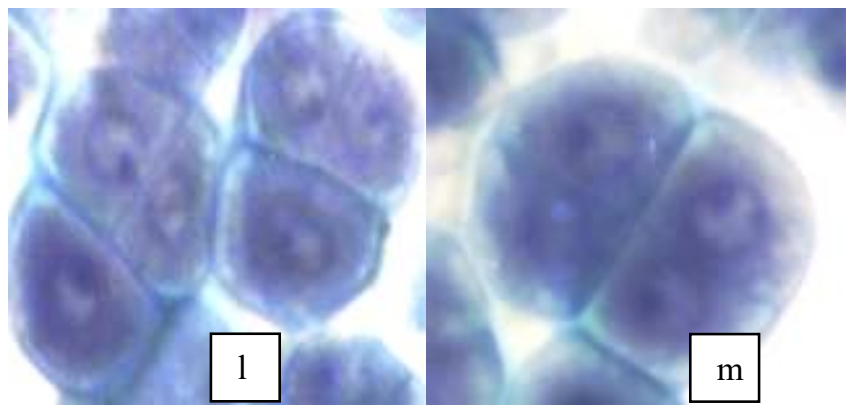

The nucleus enlarges and lies in the centre, but the cytoplasmic contents do not increase rapidly. The tapetal cells started disorganizing with the formation of tetrad after meiosis- II. The tetrad then separated either in a horizontal plane or vertical plane to produce a pair of pollen grains. Callose wall around the tetrad remain for quite sometime (m) and disappear when the pollen grains are shed in pairs (n).
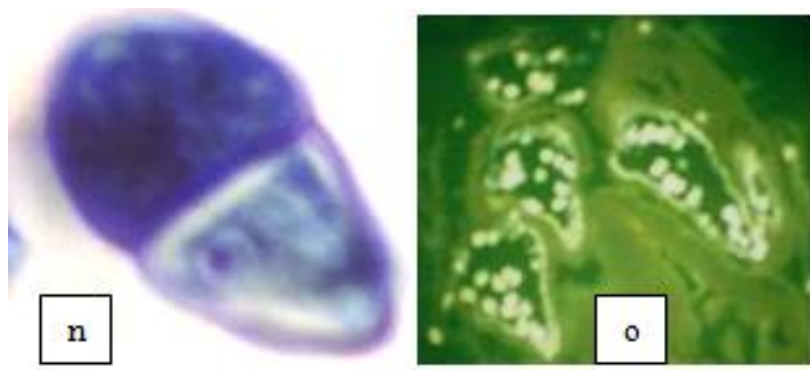

Subsequently, the cytoplasmic content increases rapidly and the nucleus moves to the distal end, thereby forming vegetative and generative cells. The shape of a pollen grain is established with thick rigid pollen wall and shows a tapering end in one side of the double pollen grain (n). Because of the callose wall deposition, the pollen grains give fluorescence with aniline blue under fluorescence microscope (o). Germinated pollens are observed on the stigmatic surface in the natural conditions (q).

\section{Volume 4 Issue 12, December 2015}




\section{International Journal of Science and Research (IJSR) \\ ISSN (Online): 2319-7064}

Index Copernicus Value (2013): 6.14 | Impact Factor (2014): 5.611

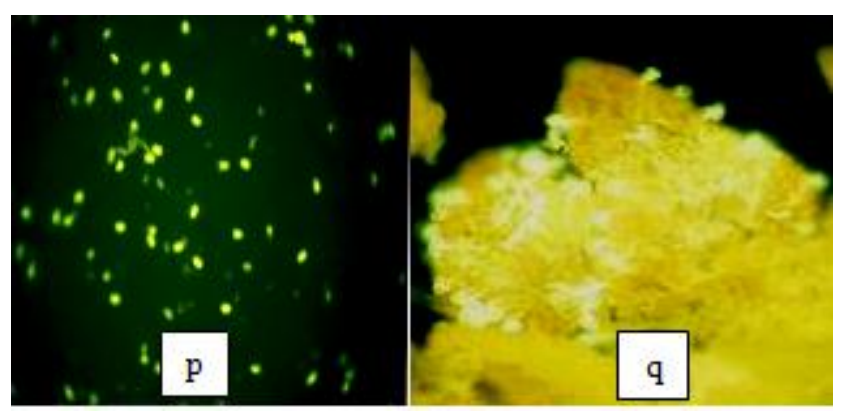

\section{Pollen Grains:}

Pollen grains of Hydrobryum are dyads (n). The dyad is about $20-25 \mu \mathrm{m}$ long and $9-11 \mu \mathrm{m}$ broad. Individual grains of dyad are subprolate in structure and triaperturate with apertures aligned between grains of the dyad. Pollen grains are circular in polar view The apertures often called colpi have weakly defined margins and range in morphology from oblong furrows with broadly rounded ends to large oval shaped pores. Ornamentation microechinate with processes of different size including pads.

The viability of pollen was studied with Flourochromatic Reaction (FCR) test and is expressed in terms of percentage. The viable pollens fluoresce brightly and non-viable one didn't fluoresce ( $p \& q)$. Reading was taken in such a way that ten microscopic fields were observed in H. griffthii, the mean value of which was taken as a total number of pollen grains. Hydrobryum griffithii shows moderately high pollen viability. The test revealed that $73.68 \%$ of pollen grains were viable.

\section{Discussion:}

Tetrasporangiate anthers have been reported in majority of angiosperm families [4]. In Hydrobryum griffithii, the two staminal primordial arise independently; because of the intercalary growth of andropodium, it becomes bifid or forked. The two forked stamen exceeding the ovary and lie close to the stigma. Intercalary growth of andropodium has also been reported in N. khasiana and N. lowii [5].

A plate of 3-4 cells of hypodermal origin in Hydrobryum function as archesporial initial. A similar type of hypodermal cell has also been reported in many plants $[6,7,8]$. However, the present study reveals that the anther wall consist of only endothecium and tapetum. Middle layer is absent in Hydrobryum. The pro-orbicules or Ubisch bodies appear in the tapetum by the time when the microspore mother cells completed meiosis-I and enter into the meiosis-II in all the three plants. As soon as cell division is completed, these granules are released in the anther locules; engulfed and deposited on the tetrads.

Meiosis is not uniform in all the four thecae of an anther lobe. This feature has not been recorded so far in any member of Podostemaceae. The cell division is successive type in which the meiosis-I is followed by centrifugal cell plate formation, after which the two daughter cells are enclosed by distinct callose wall that the resultant cells lie side by side in the common callose wall.

Pollens grains are relatively small, spherical and microechinate. Understanding of various factors influencing pollen germination and tube growth is prerequisite for the success of hybridization program $([9,10]$. However pollen viability should be considered different from germination, for instance, self or cross incompatible pollen, though viable may fail to germinate due to lack of certain essential factors [11].

In the present study, Hydrobryum show high pollen viability (73.68\%) suggesting that the pollen grains are in a highly active metabolic state and, as a result, the biochemical changes takes place over time and one could expect more viable seeds with high pollen viability.

\section{References}

[1] C.T. Philbrick, A.R. Novello, "Flowering phenology, pollen flow and seed production in Marathrum rubrum (Podostemaceae)," Aquatic Botany, (62), pp. 199- 206, 1998.

[2] C. Khosla, K.R. Shivanna, H.Y. Mohan Ram, 2000. Reproductive biology of Polypleyrum stylosum (Podostemaceae). Aquat. Bot. ( 67), pp. 143-154, 2000.

[3] A.J. Mukkada, Morphological and embryological studies on Some Indian Podostenmaceae, Ph D Thesis, University of Delhi, Delhi, India, 1962.

[4] N.N. Bhandari, "The microsporangium," in Embryology of Angiosperms, B.M. Johri (ed) pp. 53122. Springer, Berlin, Heidelberg, New York, Tokyo, 1984.

[5] N. Venugopal, N. Rashi Devi, "Development of Anther in Nepenthes khasiana of North East India," Feddes Repert. (114), pp. 67-73, 2003.

[6] P. Maheshwari, An introduction to the embryology of angiosperms. McGraw Hill, New York, 1950.

[7] K. Perisamy, B.G.L. Swamy, "Studies in Annonaceae, 1- Microsporogenesis in Cannanga odorata and Millusa wightiana," Phytomorphology (9) pp. 251263, 1959.

[8] K. Perisamy, M.K. Kandasamy, "Development of the anther of Annona squamosa L," Ann. Bot. (London) (48) pp. 885- 893,1981.

[9] I.K. Vasil, "Effect of Boron on Pollen germination and pollen tube growth," in Pollen physiology and fertilization H.F. Linkens (ed), pp. 107-113, NorthHolland Pub. Co. Amsterdam, 1964.

[10] S.T. Mercy, S.N. Kakar, T.M. Vaghese, "Studies on nutritive requirements and preservation of pollen in Cicer arietinum and C. songericum," in Physiology of sexual reproduction in flowering plants, Malik C.P. et al (eds), pp. 217- 226, Kalyani Pub. New Delhi, India, 1978.

[11] S. Goswami, Reproductive biology of Schima wallichii (DC) Korth. and Schima khasiana (Dyer) Bloemb, Ph. D Thesis, Department. Botany, North-Eastern Hill University, Shillong, pp 41, 2002.

\section{Author Profile}

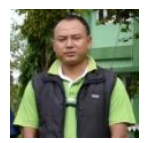

H. Lalruatsanga received his Master's and Doctorate degree from North-Eastern Hill University, Shillong, Meghalaya. He is presently working as Assistant Professor in the Department of Botany, Pachhunga University College, Aizawl, Mizoram.

\section{Volume 4 Issue 12, December 2015}

